\title{
PENERAPAN TEORI COMFORT KOLCABA DAN SELF CARE OREM PADA PASCA BEDAH SESAR PRIMIPARA
}

\section{Application of Kolcaba's Comfort Theory and Orem Self Care In Post Primiparous Cesarean Section}

\author{
Aida Kusnaningsih"* \\ *IStaf Pengajar Poltekkes Kemenkes \\ Palangka Raya, Palangka Raya, \\ Kalimantan Tengah, Indonesia
}

*email:Aidaparyanto@yahoo.co.id

\begin{abstract}
Abstrak
Persalinan dengan bedah sesar merupakan tindakan pembedahan dengan tujuan untuk menyelamatkan ibu dan bayi yang berisiko, ketika persalinan pervaginam tidak dapat dilakukan. Persalinan bedah sesar memberikan efek fisik maupun psikologis, sehingga peran perawat sangat diperlukan dalam membantu pasien mengurangi efek yang terjadi. Tujuan umum dari penulisan ini adalah untuk memberikan gambaran tentang keperawatan dengan berfokus pada aplikasi teori Self Care Orem dan Comfort Kolcaba pada ibu pasca bedah sesar primipara. Metode yang digunakan adalah studi kasus dengan penerapan Teori Self Care Orem dan Comfort Kolcaba pada lima kasus perempuan dengan pasca bedah sesar primipara di RSUPN Dr. Cipto Mangunkusoma Jakarta. Aplikasi teori ini telah membantu pasien sesar melakukan perawatan diri dan bayi baru lahir.
\end{abstract}

\begin{abstract}
Delivery by section caesarea is surgical to save mother and baby who risk condition, and cannot give vaginal delivery. Section caesarean can cause effect physical, psychology problem, and role nursing to reduce effect and help patient. This study aimed to depict the implementation of the nursing with focuses application the theory or comfort Kolcaba and self care Orem on the case of primipara post caesarean section. The method used is a case study with the application of the Orem Self Care Theory and Comfort Kolcaba in five cases of women with post-primiparous cesarean section at Dr. RSUPN. Cipto Mangunkusoma Jakarta The application the theory help post caesarean patient to comfort/reduced pain and increase ability self care and newborn.
\end{abstract}

Keywords:
Section Caesarean

Comfort Kolcaba

Self Care Orem sa/4.0/). DOI: https://doi.org//0.33084/jsm.vxix.xxx.

\section{PENDAHULUAN}

Angka Kematian lbu (AKI) merupakan indikator yang menggambarkan dan menentukan status kesehatan ibu. Pembangunan kesehatan melalui Substainable Development Goal (SDGs) menetapkan target untuk mengukur kemajuan Pembangunan Manusia (Human Development) dengan menurunkan AKI pada tahun 2030 yaitu 70 per 100.000 Kelahiran hidup. Masalah yang dialami oleh Negara berkembang termasuk Indonesia saat ini adalah masih tingginya angka kematian ibu (AKI). World Health Organization (WHO) 2012 melaporkan bahwa AKI di dunia tahun 2010 sebesar 210 per 100.000 kelahiran hidup. Di Indonesia angka kematian ibu meningkat dari 228 pada tahun 2007 menjadi 359 per 100.000 kelahiran hidup pada tahun 2012 (IDHS,
20I3). Tingginya AKI salah satunya disebabkan oleh komplikasi kehamilan, persalinan, nifas dan segala intervensi dan penanganan tidak tepat dari komplikasi tersebut (Kemenkes, 20I2).

Penurunan AKI juga dapat dilakukan dengan memberikan pelayanan yang tepat dan cepat dengan melihat ibu dari factor 3 terlambat dan empat terlalu (UNFPA). Pada kondisi ibu dan janinnya dalam kondisi berisiko maka dilakukan tindakan pembedahan (bedah sesar) untuk mempercepat kelahiran dan mencegah bahaya pada ibu dan bayi baru lahir (Reeder, Martin, \& Griffine, 1997/20II). Hasil Rikesdas Tahun 2013 menunjukkan kelahiran dengan bedah sesar sebesar 9,8\% dengan proporsi tertinggi di DKI Jakarta dan terendah di Sulawesi Tenggara (Kemenkes RI, 20I3). 
Persalinan dengan bedah sesar dapat memberikan efek bagi kondisi fisik dan psikologis ibu, efek tersebut antara lain nyeri luka operasi, afterpain, ketidaknyamanan pada payudara, menyusui bayi, ketidaknyamanan area genital dan pelvic, gangguan tidur dan kelelahan (Cheng, Fowler, \& Walker, 2006; Kempler, Sharpe, \& Bartlett, 2012; Kurth et al., 2010). Oleh sebab ibu perlunya penatalaksanaan yang tepat dan akurat sehingga tidak terjadi akibat lanjut yang dapat merugikan dan mengancam keselamatan pasien. Hal ini salah satunya dapat dilakukan oleh perawat maternitas.

Perawat spesialis keperawatan maternitas sebagai pemberi pelayanan kesehatan memmpunyai tanggung jawab professional dan peran multidimensional yaitu sebagai praktisi dengan melakukan pendekatan proses keperawatan yang berfokus pada kebutuhan biopsikososial dan spiritual berdasarkan konsep teori keperawatan konsep teori keperawatan yang dilakukan pada semua masalah kesehatan perempuan melalui asuhan keperawatan yang komprehensif. Peran yang dapat dilakukan oleh perawat maternitas dalam memberikan asuhan keperawatan komprehensif kepada pasien adalah educator, konselor, kolaborator, koordinator, innovator, advocate dan peneliti (Reeder, Martin, \& Griffine, 1997/20 I I; Sudan, \& Shelton, 2009). Asuhan keperawatan yang komprehensif pada pasien pasca bedah sesar dapat dilakukan oleh perawat maternitas dengan menggunakan Teori Self Care Orem dan Comfort Kolcaba. Teori Self Care Orem menitikberatkan pada kemandirian pasien terhadap bantuan perawatan. Ada tiga aspek kebutuhan pasien terhadap bantuan perawatan yaitu bantuan total (wholly compensatory system), bantuan sebagian (partially compensatory system) dan bantuan minimal (supportive educative system), sedang teory comfort Kolcaba memandang bahwa kemampuan kenyamanan yang spesifik, ease terbebas dari ketidaknyamanan dan transcendence mampu bertoleransi terhadap rasa nyeri (Alligood, \& Tomey, 20l0). Kondisi ini menunjukan bahwa perlu dilakukan penerapan asuhan keperawatan pada pasien pasca bedan sesar primipara menggunakan pendekatan teori Self Care Orem dan Comfort Kolcaba.

\section{METODOLOGI}

Metode yang digunakan adalah studi kasus dengan penerapan Teori Self Care Orem dan Comfort Kolcaba pada lima kasus perempuan dengan pasca bedah sesar primipara di RSUPN Dr. Cipto Mangunkusoma Jakarta.

\section{HASIL DAN PEMBAHASAN}

\section{HASIL}

Asuhan keperawatan yang dilakukan yaitu pada fase akut dengan menggunakan teori Comfort Kolcaba dan fase pemeliharaan menggunakan teori Self Care Orem. Pengkajian dengan pendekatan teori Comfort Kolcaba dilakukan pada empat aspek yaitu fisik, psikospiritual, lingkungan dan sosial, sedangkan teori Self Care Orem yaitu Universe Self Care Requisities, Conditioning Factor Requisities, Developmental Self Care Requisities, Health Deviation Self Care Requisities, Terapeutik Self Care Demand, Self Care Deficit, Nursing Agency dan Nursing System.

Setelah data pengkajian didapat, dilakukan penyusunan diagnosa keperawatan. Diagnosa keperawatan yang muncul pada kelima kasus adalah gangguan rasa nyaman nyeri berhubungan dengan luka operasi, dan ketidakmampuan mengontrol rasa nyeri, kemampuan perawatan diri dan bayi berhubungan dengan kurangnya pengetahuan tentang perawatan diri pasca bedah dan perawatan bayi baru lahir, dan meningkatkan control pencegahan infeksi.

Intervensi keperawatan bertujuan untuk meningkatkan kenyamanan dan meningkatkan kemandirian pasien dalam perawatan diri pasca bedah dan bayi baru lahir. Evaluasi keperawatan berfokus pada evaluasi dari keefektifan intervensi keperawatan yang telah dilakukan yang berhubungan dengan perilaku individu. Evaluasi dilakukan secara terus menerus dan berkelanjutan untuk mengevaluasi kemajuan pasien dalam mencapai kriteria yang telah ditetapkan. 


\section{PEMBAHASAN}

Aplikasi teori Self Care Orem dan Comfort Kolcaba digunakan melalui pendekatan proses keperawatan dimulai pengkajian sampai dengan evaluasi. Hasil pengkajian lima kasus kelolaan didapatkan indikasi pasien dilakukan bedah sesar adalah letak lintang, ketuban pecah dini, solusio plasenta, gawat janin, preeclampsia, dan CPD. Penelitian Andayasari et al (2015) didapatkan proporsi gawat janin pada persalinan bedah sesar sebesar 22\%, dan indikasi KPD sebesar $21,8 \%$. Penelitian Muhammad et al (2014), bedah sesar dengan indikasi gawat janin sebesar $28,7 \%$. Sectio caesarea dilakukan jika terjadi gawat janin, disproporsi sepalopelvik, persalinan tidak maju, plasenta previa, prolapsus tali pusat, malpresentasi janin atau letak lintang (Sumelung et al, 2014).

Pasien primipara pasca bedah sesar pada lima kasus kelolaan, indikasi dilakukan tindakan bedah sesar adalah PEB, KPD, Gawat Janin, solusio plasenta, dan kelainan letak. Empat dari lima pasien yang menjadi kelolaan mempunyai bayi premature (lahir sebelum usia kehamilan 37 minggu) dan berat badan kurang dari 2500 gram (berat badan lahir rendah/BBLR). Kondisi ini sejalan dengan beberapa hasil penelitian yang telah dilakukan. Penelitian Nurliawati (20I4), ada hubungan yang signifikan antara riwayat kehamilan dengan ibu dengan PEB dan BBLR, ibu dengan riwayat PEB mempunyai risiko 86,7 kali lebih besar untuk melahirkan bayi BBLR dibandingkan dengan ibu yang tidak mempunyai riwayat PEB ( $P=0,000$ dan $O R=86,778)$. Penelitian Okeke et al (2014) menunjukkan hasil bahwa KPD memicu satu dari kelahiran premature.

Masalah nyeri disebabkan oleh adanya luka operasi dan kontraksi uterus. Cheng, Fowles, \& Walker (2006); Kempler, Sharpe, \& Bartllett (2012); Kurth et al., 2010 bahwa persalinan dengan bedah sesar dapat memberikan efek bagi kondisi fisik maupun psikologis ibu. Efek tersebut antara lain luka operasi, afterpain, ketidaknyaman pada payudara, menyusui bayi, ketidaknyamanan area genital dan pelvik, gangguan tidur dan kelelahan. Reeder, et al, 1997/201 I, nyeri setelah kelahiran sesar kebanyakan disebabkan oleh luka di daearah insisi, dan kembung karena tertahannya gas saat fungsi usus dalam pemulihan.

Ketidakmampuan merawat diri pada lima kasus kelolaan selain disebabkan nyeri dan kelemahan, juga disebabkan karena tidak ada pengetahuan dan pengalaman dalam perawatan diri ibu nifas dan perawatan bayi baru lahir. Notoatmojo (2010), bahwa pengetahuan dapat diperoleh dengan cara kuno yaitu berdasarkan pengalaman pribadi. Pengalaman pribadi dapat digunakan sebagai upaya untuk memperoleh pengetahuan dengan cara mengulang kembali pengalaman yang pernah diperoleh dalam memecahkan permasalahan yang dihadapi di masa lalu.

Intervensi keperawatan bertujuan untuk meningkatkan kenyamanan dan meningkatkan kemandirian pasien dalam perawatan diri pasca bedah ssar dan bayi baru lahir. Salah satu intervensi yang dilakukan adalah mengajarkan alternative pengelolaan nyeri nonfarmakologi yaitu relaksasi Benson.

Relaksasi Benson merupakan suatu teknik relaksasi yang merupakan penggabungan antara teknik respon relaksasi dengan sistem keyakinan individu/ faith factor (difokuskan pada ungkapan tertentu berupa nama-nama Tuhan, atau kata-kata yang memiliki makna menenangkan bagi pasien itu sendiri) diucapkan berulang-ulang dengan ritme yang teratur disertai sikap pasrah (Benson, \& Proctor, 2000). Penelitian menunjukkan relaksasi Benson efektif menurunkan nyeri pada pasien pasca bedah sesar. Penelitian Yusliana, Misrawati, dan Safri (2015) menunjukkan hasil relaksasi Benson efektif terhadap penurunan nyeri ibu postpartum section caesarea $(p=000)$.

Masalah yang dialami oleh pasien pasca bedah sesar adalah ketidakmampuan merawat diri dan bayi baru lahir. Intervensi yang diberikan yaitu memberikan pendidikan kesehatan perawatan diri ibu pasca bedah sesar meliput mobilisasi, pemenuhan nurtrisi dan cairan, personal hygene, pemenuhan kebutuhan eliminasi 
istirahat tidur dan perawatan payudara dan tanda bahaya masa nifas dan perawatan bayi baru lahir meliputi teknik perawatan bayi baru lahir, cara memandikan bayi, membedong bayi, cara menjaga kehangatan bayi, cara mencegah bayi dari infeksi, cara memberikan makanan pada bayi, dan cara membersihkan kulit bayi.

Faktor yang sangat paling berpengaruh dalam mobilisasi pasien pasca bedah sesar adalah pemberian informasi oleh petugas kesehatan (Exp (B) : 4,200) (Hartati, Setyowati, dan Afiyanti (20I4). Puspitasari (20I0) dalam penelitiannya menyatakan ada beberapa faktor yang memengaruhi dalam proses penyembuhan luka bedah sesar diantaranya adalah penyakit diabetes mellitus, personal hygiene dan nutrisi. Perawatan payudara bertujuan untuk mempertahakan produksi asi agar tetap lancar dan mencegah terjadinya bendungan pada saluran asi (Reeder et al., 1997/20II; Pilliteri, 2010; Richi, 2009).

Evaluasi keperawatan dilakukan pada masing-masing diagnosa keperawatan. Evaluasi ini mengacu pada keberhasilan pencapaian kenyamanan/penurunan rasa nyeri dan tingkat kemandirian pasien pasca bedah sesar primipara dalam perawatan diri dan bayi baru lahir.

\section{KESIMPULAN}

Aplikasi teori Comfort Kolcaba dan Self Care Orem dapat diterapkan pada ibu pasca bedah sesar primipara dari tahap pengkajian sampai dengan evaluasi. Hasil evaluasi didapat bahwa kelima kasus kelolaan mengalami peningkatan rasa nyaman dan kemandirian dalam perawatan diri dan bayi baru lahir.

\section{REFERENSI}

I. IDHS. (20I3). Statistics Indonesia National Population and Family Planning Board. Jakarta: Ministry of Health Measure DHS ICF International.

2. Kemenkes RI. (20I2). Kajian Determinan Kematian Maternal di Lima Region. (Jakarta: Kemenkes RI). Retrieved from http://www.kesehatanibu.depkes.go.id/wpcontent/ plugin/downloadmonitor/download.php\%3.

3. Kemenkes RI. (20I3). Riset Kesehatan Dasar RIKESDAS Tahun 2013. Jakarta: Kementerian Kesehatan RI.

4. Cheng, Fowles, \& Walker. (2006). Postpartum maternal health care in the united states: a critical review. Journal of Perinatal Education, 15(3), 34-42. doi: 10.1624/I058I2406XI 19002.

5. Kempler, L., Sharpe, L., \& Bartlett, D. (20I2). Sleep education during pregnancy for new mothers. BMC Pregnancy and Childbirth, 2,155. doi:I0.1 186/I47I2393-12-155.

6. Reeder, S. J., Leonide, L., \& Grifin, D. K. (1997). Maternity Nursing: Family, Newborn, and Women Health Care. $18^{\text {th }}$ Ed. Alih bahasa Yati Afiyati, Imami Nur Rahmawati, Sri Djuwitaningsih (20II) Keperawatan Maternitas: Kesehatan Wanita, Bayi dan Keluarga, Ed 18 Vol I. Jakarta: EGC.

7. Sudan, L., Ward, \& Shelton, M.H. (2009). Maternal Child Nursing Care. Philadelphia: F.A Davis Company.

8. Alligood, \& Tomey. (2010). Nursing Theory Utilization and Application (Third Edition). United States of America: Mosby.

9. Andayasari, L., Muljati, S., Sihombing, M., Arlinda, D. Opitasari, C., Mogsa, D. F., \& Widianto. (20I4). Proporsi Seksio Sesarea dan Faktor yang Berhubungan dengan Seksio Sesarea di Jakarta. Buletin Penelitian Kesehatan, 43(2), I05-II6.

I0. Sumelung, V., Kundre, R., \& Karundeng, M. (20I4). Faktor-faktor yang berperan meningkatkan angka kejadian section caesarea di rumah sakit umum daerah liun kendage tahuna. Ejournal Keperawatan, 2(1), I-7.

II. Nurliawati, E. (20|4). Hubungan antara preeclampsia berat dengan bayi berat badan lahir rendah (bblr) di rsu dr. sokardjo kota tasikmalaya tahun 2013. Jurnal Kesehatan Bakti Tunas Husada, I2(I). 22-27 
12. Okeke, T. C., Enweriji, J. O., Okoro, O. S. Adiri, C. O., Ezugwu, W. C., Agu, P. U. (20/4). The incidence and management outcome of premature ruftur of membrane in tertiary hospital and Nigeria. American journal clinical medical research, 2(I), 14-17.

13. Notoatmodjo, S. (20I0). Promosi Kesehatan dan Ilmu Perilaku. Jakarta: Rineka Cipta

14. Yusliana, Misrawati, \& Safri. (20I5). Efektifitas Relaksasi Benson Terhadap Penurunan Nyeri Pada Ibu Postpartum Section Caesarea. JOM. 2(2). 944952

I5. Hartati, S., Setyowati, dan Afiyanti, Y. (20/4). Faktor-faktor yang memengaruhi ibu postpartum pasca section caesarea untuk melakukan mobiliasi dini di RSCM. Journal Keperawatan, 5(2), 192-197 EISSN 2443-0900.

16. Puspitasari, Herlina, A., Ummah, B. A., \& Sumarsih, S. (20II). Faktor-faktor yang memengaruhi penyembuhan luka post operasi section caesarea. Journal Ilmiah Kesehatan Keperawatan, 7(I).

17. Pilliteri, A. (20/0). Maternal And Child Health Nursing. Care Of The Childbearing And A Childbearing Family. $6^{\text {th }}$ ed. Lippincott: William \& Wilkins. 